\title{
Considering the Effects of Potassium on Manganese and Soil Fertility
}

\author{
Neal Kinsey* \\ B.S. \& B.A. and Certified Soil Fertility Specialist, USA
}

Submission: September 26, 2017; Published: October 16, 2017

"Corresponding author: Neal Kinsey, B.S. \& B.A. and Certified Soil Fertility Specialist, USA, Email: neal@kinseyag.com

\section{opinion}

Potassium is considered as a primary nutrient needed in all types of agricultural production. It helps provide cold tolerance to plants. It also aids in water utilization, or as an old saying goes, "Potassium is the poor man's irrigation" and all crops benefit in that way when it is properly supplied. Also, when sufficiently available, potassium is a major key for strengthening and encouraging strong cell wall development and thus enables stronger wood or stronger stalks depending on the crop being grown.

But when overused, potassium has some serious drawbacks. A severe excess of potassium in the soil will cause the clay particles to disperse and clog needed pore space so that water will tend to stand on top instead of infiltrating the soil as it would under normal circumstances. Excessive potassium can also adversely affect nutrient availability, including the tie-up of boron and blocking of adequate manganese uptake from the soil. This holds true for all types of crops, but due to generally common practices, an example from potato production should serve as a prime example to show how excessive potassium can cause problems regardless of the crop to be grown.

Most potato growers feel that to produce good yields the practice of applying large amounts of fertilizer, and especially plenty of potassium right under the seed row is an absolute must. The perception is that potato roots do not spread outward very well, and that they tend to grow straight down below where the seed is placed. Such downward root growth does show to be the case in many fields where potatoes are grown. However, based on growth exhibited in fields that have been supplied with the correct amount of each needed nutrients, such limited root growth is actually abnormal as compared to what should and does happen on potato fields with sufficiently adequate levels of fertility.

In fact, when soil fertility reaches the desired level for growing potatoes, the plants will send out roots that will spread across the middles, growing right on past roots coming from the next adjacent row of potatoes on each side. When possible, roots grow to where the needed nutrients can best be obtained. Because of the false perception that potato roots do not or will not spread out, large amounts of fertilizer ordinarily tends to be placed directly under each row and the roots grow straight down to pick it up.

This common practice can contribute to certain problems for reaching optimum levels of potato production. One such negative set of consequences has to do with soil nutrient supplementation and plant nutrient uptake. The soil is the plant's stomach. Feed the soil and the soil will then properly supply nutrients to the crop. Therefore, when misconceptions begin to influence growers to forego the needs of the soil and instead apply only what is perceived as needed to grow the crop, soil health and plant health can be adversely affected.

Furthermore, depending on various nutrient levels unique to each individual soil, a number of possible problems can develop or become even more seriously aggravated by applying excessive amounts of potassium fertilizer right under the row. One such example involved a large potato grower/processor in Africa that hired us for a farm visit to consider a problem they were concerned about in the potato crop. The potatoes would begin to grow off well, but then suddenly the plants would develop weak stalks and the vines would fall over, resulting in scorching or sun scald permanently left on the stalks.

Then after a time, the potatoes would stand back up and begin to grow as they should have all along. But consequently they had been injured by the sun and the concern was how much this damage was affecting potato yields and how to prevent it from happening time after time. The first rule to consider in such cases is what Dr. Andre Voisin called, "The Law of the Maximum." Too many, if not most farmers and growers, fail to consider or seriously place sufficient emphasis on understanding and 
utilizing this concept. Consequently it has cost far too many farmers, and especially potato growers in this particular type of case, large sums of money due to reduced growth and yields.

Soil samples were already in hand for these soils that had been taken and sent for a detailed analysis and recommendations. With a copy of the tests for the fields in hand it was possible to evaluate the current conditions standing right there in the field looking at the growing plants. Potassium levels were quite good in the fields, but still some additional potassium was needed to achieve the potato yields these fields had the ability to produce. And even though the recommendations plainly stated all fertilizers were to be broadcast, the grower still had applied potassium under the row just as most potato growers always do.

When everybody does it, it must be the correct thing to do right? Well, not in this case! Placing the needed potassium directly under the row caused the available potassium level in the soil to increase by too much. In such cases, the first effect is to tie up boron in the soil. Because once potassium exceeds $7.5 \%$ of the soil nutrient holding capacity or Total Exchange Capacity (commonly confused with the "CEC" measurement which often causes this number to be overstated), it will begin to tie up the boron. Then if enough boron is not replaced via foliar applications it can result in smaller potatoes, because boron is needed to transport the starch out of the leaf and move it into the tubers. But even though the lack of boron was affecting the size and weight of the crop, it was not what was causing the temporarily weakened stalk problem and reduced stalk growth for this African grower. Where too much potassium is applied right under the row, if either by itself, or in combination with sodium, the total saturation exceeds $10 \%$ of the soils nutrient holding capacity (TEC), it will begin to cause plant uptake of manganese to be blocked. In such cases, soil tests show the soil has plenty of manganese, but there is so much potassium and/ or sodium there that the manganese has trouble competing in terms of availability and uptake by the potato. This was the problem the potatoes were having in this grower's fields. The higher the percentage goes above $10 \% \mathrm{~K}$, the harder it will be to get manganese taken up by the plants even though the soil test may show excellent manganese levels. Even though the excessive level of potassium does not tie up the availability of manganese in the soil, it does, along with sodium, block adequate manganese uptake via the soil into the plant.

When the potassium and other nutrients were placed below the seed, the potatoes sent their roots right on down to take up needed nutrients. But the extra potassium applied in that confined area was too much for that soil and once the potato roots entered that area, the blocked uptake of manganese caused weakened stalks and the problem that resulted in sun scald on those stalks. Potassium is the first key to stalk strength, but manganese is also needed for strong stalks. When the potatoes could not take up enough manganese, all that potassium was no substitute for the needed manganese. The potato stalks became weak and fell over. Once the roots were sufficiently able to grow out of that excess potassium zone, the plants could again take up enough manganese and the vines straightened up and began to grow as they should.

That was several years ago and since that time, no potassium is recommended under the row on potato land for that company except in the case of new land with extreme $\mathrm{K}$ deficiency. In potassium deficient soils, there will be no problem with weak stalks in potatoes grown there as long as the fertilizer is added in the proper way. Even though very important to stalk strength in all crops, manganese provides several other benefits for land being used for crop production and when too much potassium is applied, it will contribute to these problems as well. Without manganese plants grow off more slowly. A lack of it also affects seed set. And for potatoes, in terms of common scab, the worse the manganese deficiency in the soil, the more problem there will be with this disease.

One big problem for growers is knowing what really is enough manganese in the soil for each crop? The answer tends to be confusing because of the various ways to measure and report manganese on soil tests. In fact, the numbers we recommend just to be at adequate levels in the soil will be reported as high to excessive levels on some other soil test reports. There is yet another problem that growers may have in trying to determine when there is sufficient manganese for the crop. This has to do with using a leaf analysis to determine if plants have sufficient or insufficient manganese. When the specific soil test we utilize shows manganese as even slightly deficient, common scab can be a problem for potatoes. Yet in too many cases, the leaf analysis shows the level of manganese to be adequate, even when our testing still shows manganese as deficient in the soil. Which should be believed? The one that solves the problem!

Keep in mind that many potato growers use a metallic manganese based foliar to treat for disease. This can greatly skew the levels shown from the leaf test. But this is not the entire story. Potatoes have been used as an example here due to their extreme sensitivity to manganese deficiency. And at times, even those who have not used a foliar manganese can have leaf tests that show manganese as too high when in actuality the soils are still too deficient to correctly supply plant needs. We find this consistently tends to be the case with leaf testing for most micronutrients, not just manganese, as compared to the levels shown to be required on the soil test to properly solve each deficiency. Such deviations can also be a serious problem when considering needs for other manganese sensitive crops such as wheat, grapes and all types of trees, but especially English walnuts and black walnuts.

There is still another precaution that should be considered when evaluating available levels of manganese for crop production. Even leaving dust on the leaves can cause manganese levels to appear to be too high in the plant. A good way to detect this is when iron and aluminum are also shown to be extremely high on the same analysis. When that happens, test again with 
clean plant tissue to be sure. Perhaps an additional word of caution should be given here, for even soils that may initially have an adequate amount of manganese can develop a deficiency problem if enough lime is applied to cause manganese to go from sufficient to deficient.

This can happen when any material containing a sufficient amount of calcium is applied on soils that barely have enough manganese (with even worse results when the soil is already deficient in manganese), because when calcium is applied, as it becomes available over the next one to three years, it will tie up a certain amount of soil-available manganese. If the soil has enough to stand the amount of calcium applied, manganese will not become the problem there as a result of applying needed lime. That is one reason why in some areas potato growers can apply calcium limestone and have no problem with common scab, but in other areas no one will dare apply it. And due to soils needing calcium for adequate uptake of all the other nutrients (including N-P-K) if the problem is not solved, crop production will not only suffer but may even decline in terms of yield.

Yet the issue of adequate manganese in the soil can be overcome by applying a sufficient amount of the correct type manganese sulfate. The needed amount should be based on a detailed soil analysis which can accurately determine the desired level in the soil. The test should be such that it can accurately determine how much manganese is required to overcome any tie-up from added calcium as well. Whether already deficient, or for a potential decrease in manganese due to liming or other sources of calcium (such as poultry manure), only the use of true manganese sulfate should be considered for adding to the soil to sufficiently build up the manganese level to solve that need. From the testing we use, that need will be reflected and solved based on the use of one pound of actual manganese for every pound shown to be lacking. If that does not happen in the next twelve months after an initial application, someone is likely providing the wrong advice. Though comparatively few in number, there are some soils where manganese does not build well. Waterlogged soils are generally the best examples. Heavy coarse yellow clays can also be quite deficient and hard to build up and maintain. When using manganese oxide or manganese oxy-sulfate the soil analysis has never shown to increase soil manganese levels, let alone help build up to adequate levels. Although oxy-sulfate may help feed the plant if enough is applied for each given set of needs, it will only help for the current crop year at best.

Some soils do not even build well using manganese sulfate. In a very few cases it has been necessary to apply the needed amount for two or three years in a row to reach the desired minimum level. In such cases, the use of ammonium sulfate as a nitrogen source may help, but generally the amounts used do not show much progress in building up soils deficient in manganese. A crop which can also help to increase manganese availability in the soil is rice. Just keep in mind that the primary elements, $\mathrm{N}-\mathrm{P}-\mathrm{K}$, truly are primary in terms of getting enough nutrients there to grow the crop. But when any one of these three are overapplied, providing more than the soil can tolerate, those same elements can cause a whole new set of problems, not just for potatoes, but for all types of crops and growing plants.

This work is licensed under Creative Commons Attribution 4.0 License DOI:10.19080/ARTOAJ.2017.12.555831
Your next submission with Juniper Publishers will reach you the below assets

- Quality Editorial service

- Swift Peer Review

- Reprints availability

- E-prints Service

- Manuscript Podcast for convenient understanding

- Global attainment for your research

- Manuscript accessibility in different formats

( Pdf, E-pub, Full Text, Audio)

- Unceasing customer service

Track the below URL for one-step submission https://juniperpublishers.com/online-submission.php 